\title{
Mis-naming and Mis-labelling in The Namesake by Jhumpa Lahiri
}

\section{Françoise Král}

\section{(2) OpenEdition \\ 1 Journals}

Electronic version

URL: https://journals.openedition.org/ces/5292

DOI: $10.4000 /$ ces.5292

ISSN: 2534-6695

\section{Publisher}

SEPC (Société d'études des pays du Commonwealth)

\section{Printed version}

Date of publication: 1 September 2013

Number of pages: 93-101

ISSN: 2270-0633

\section{Electronic reference}

Françoise Král, "Mis-naming and Mis-labelling in The Namesake by Jhumpa Lahiri", Commonwealth Essays and Studies [Online], 36.1 | 2013, Online since 16 April 2021, connection on 22 July 2021. URL: http://journals.openedition.org/ces/5292 ; DOI: https://doi.org/10.4000/ces.5292

\section{(c) $($ () $\ominus$}

Commonwealth Essays and Studies is licensed under a Licence Creative Commons Attribution - Pas d'Utilisation Commerciale - Pas de Modification 4.0 International. 


\section{Mis-naming and Mis-labelling in The Namesake by Jhumpa Lahiri}

In this article I propose to reposition the issue of mis-naming and mis-labelling away from the psychological focus the novel invites as a critical response, and suggest a reflexion on some of the perspectives which Lahiri's indictment of labels opens onto, such as that of symbolic filiation or the redefinition of labels in the American context, as well as their role in the dynamics of mixing and merging the various ethnic groups engage in.

In My Beautiful Launderette, a film whose title refers to the "whitening"1 process inherent in racial integration (with the metaphor of the laundromat which "whitens" the motley diversity of the nation), the scriptwriter Hanif Kureishi put the following cue in the mouth of one of his characters: "I'm a professional businessman, not a professional Pakistani." The subtext of this humorous and incisive expression is a criticism of an essentialist conception of identity as predetermined rather than contextual or in Sartrean terms "situational" (Sartre, 1973 [1946] 48). But it also places emphasis, quite ironically, on the way identity - a kaleidoscope produced by several parameters such as gender, race and social background ${ }^{2}$ coming into relation with each other - finds itself reduced, either by society or by personal choice, to a given aspect that is emphasized. Such a positioning can be achieved by going against the grain of societal changes or by buying into the showcasing of certain minority groups, a phenomenon which Denise Riley has described in her book Am I that Name?:

The impermanence of collective identities in general is a pressing problem for any emancipating group. [...] While you might choose to take on being a disabled person or a lesbian, for instance, as a political position, you might not elect to make a politics out of other designations. As you do not live your life fully defined as a shop assistant, nor do you as a Greek Cypriot, for example, and you can always refute such identifications in the name of another description which, because it is more individuated, may ring more truthfully to you. Or most commonly, you will skate across the several identities which will take your weight, relying on the most useful for your purposes of the moment. (16)

Reflecting on the process of naming through a focus on the dyad names versus labels forces us to identify what is at stake on both a personal and a collective level and to distinguish between the politics of the label and the strategies of expression of one's identity, which is not to be confused with "self-representation."” It also invites us as post-colonial specialists to embrace another perspective where naming no longer rhymes with claiming, appropriating or possessing as was often the case in a colonial context. This

1. Initially theorized by Frantz Fanon through a focus on how light-coloured Martiniquan people were tempted to mimic the dominant class by "whitening their lineage," the concept of "whitening" has been extensively used in postcolonial and ethnic studies where it has served to evidence the collusion between race and power in the sense that being white also corresponds to being higher up in the social hierarchy, which explains attitudes of self-hatred in coloured populations. For further discussion of the collusion between race and power see also Balibar and Wallerstein.

2. In The Location of Culture Homi Bhabha referred to what he called "the move away from the singularities of 'class' or 'gender' as primary conceptual and organizational categories" (1).

3. The distinction between identity and self-representation is borrowed from sociology; sociologists often distinguish between identity as a set of objective parameters (such as one's level of education, social background, gender, political inclinations) as opposed to "self-representation" which is a lot more subjective and refers to how an individual conceives of himself. 
switch of perspective is, on the whole, more adequate to discuss authors who belong to the diasporic context, in the sense that unlike postcolonial writers, diasporic writers are more removed from the legacy of colonialism and the inheritance of loss than writers who write in countries that are former colonies, as they are more distant from the narratives of land lost, claimed by others and renamed. This explains why more often than not diasporic writers have ceased to see names as constricting straitjackets and often invent characters who embrace them as new avenues of self-definition and reinvention, as well as instruments of a newly defined, and not yet fully visible, collective identity. Jhumpa Lahiri's novels are characteristic of a certain trend in diasporic fiction (alongside Monica Ali for example) which consists in looking at the emancipating trajectory of second generation immigrants and in particular female characters, who embrace the diasporic experience as empowering, as opposed to their husbands or fathers who continue to position themselves in a post-colonial framework, harbouring resentment towards the colonial nation whilst showing deference to its cultural influence. This postcolonial positioning of the male characters is one of the reasons why they fail to make of the diasporic journey an empowering experience (Král, Critical Identities 2009).

Jhumpa Lahiri's novel The Namesake fits into this category of novels for it revolves around the significance of names in so far as they relate to personal identity. By confronting Eastern and Western traditions in relation to naming, it provides a critical reassessment of the expectations surrounding the collective significance of the act of naming as opposed to the personal experience of being given a name. As such, the novel opens onto a broad spectrum of issues ranging from symbolic filiation and the absence of a core culture the diasporan can relate to in the host country, to the use and misuse of labels. The novel needs to be recontextualized with respect to America and its successive redefinitions of the criteria which make immigrants eligible to become US citizens, as well as to the more recent shift from race to ethnicity. What is more, the agenda of the labelling process needs to be discussed in relation to the social consequences of labelling which, I shall argue, grant individuals a certain form of visibility in the public sphere whilst condemning them to some sort of second class existence by pinning them down as "peripheral," "other" or "marginal."

\section{The Paradigm of the Ill-fitting Overcoat}

In The Namesake, the protagonist Gogol/Nikhil Ganguli is burdened with a name which is neither American nor Indian but which comes from Nikolaï Gogol, the writer. The name was chosen by his father who, as a young man, survived a train accident; the book he had chosen to accompany him on this journey and which he was reading before the accident, Gogol's The Overcoat, remained symbolic of his miraculous survival. The foreign-sounding sonorities of the name Gogol, whose peculiar quality and whose lack of relevance become a burden to the budding self-conscious teenager, take on several meanings throughout the novel well before the moment when, as a young adult, Gogol understands the intensity of his father's near-death experience. The protagonist's struggle to come to terms with this name invites a reflexion on naming in general as the novel interrogates the social conventions inherent in the act of naming. The trajectories of the main characters, Ashima, Gogol, and Moushumi, lay emphasis on the shortcomings of names and their lack of correspondence to the characters' personalities. 
Jhumpa Lahiri's handling of the motif of naming in relation not only to Gogol but also with regard to the main characters of the novel brings together three propositions: a Derridean positioning which foregrounds what Derrida described in De la Grammatologie as "the violence inherent in the act of naming" (8); a postmodern move away from an essentialist definition of identity as fixed and stable and which the name as an ultimate signifier should ideally pin down and showcase and, last but not least, a cultural clash triggered by the pressure to name (Gogol's parents cannot leave the hospital unless their child has been given a name). Long before it becomes a burden for the teenager, the name chosen by the parents under pressure from the hospital staff is not only deemed unsatisfactory but is perceived as a form of violation by the parents. As a "pet name," as opposed to a "good name," (bhalonam in Bengali) "Gogol" should never have been used outside the family and this first transgression of the sacred line between home and outside constitutes the first instance of cultural clash in the narrative.

Every pet name is paired with a good name, a bhalonam, for identification in the outside world. Consequently, good names appear on envelopes, on diplomas, in telephone directories, and in all other public places. (For this reason, letters from Ashima's mother say "Ashima" on the outside, "Monu" on the inside). Good names tend to represent dignified and enlightened qualities. Ashima means "she who is limitless, without borders." Ashoke, the name of an emperor, means "he who transcends grief." Pet names have no such aspirations. Pet names are never recorded officially, only uttered and remembered. (26)

The two names not only correspond to the two spheres of home and domesticity as opposed to the outside world, they also have distinct temporalities, and while the pet name is only uttered in the present and has no claim to posterity, the "good name" is meant to be recorded and becomes part of collective memory.

These respective features of the "good name" as opposed to the pet name explain why the pressure put on the parents to use Gogol, a pet name, as an official name, at least for a short duration, is resented by them as a sort of violation. Interestingly enough, this original misnaming can be read as an allegory of the misnaming process which is at the heart of the diasporic experience: names are transcribed into another language, sometimes into a different alphabet, with different visual characteristics, while the sonorities are transposed, more or less successfully, into the language of the host country which only retains the sounds and loses the meaning. And the migrant who is not in a position to question anything finds himself with a name he cannot recognize. It is also ironic to think that the "good name," chosen by Gogol's grandmother in India, was placed in an envelope together with a girl's name, and that it got lost somewhere between India and America, not unlike diasporic identity which gets lost between the homeland and the host country.

In the novel names fail to be the perfect signifiers the essentialist perspective would like them to be. A name is more like a large, ill-fitting overcoat, an overcoat one grows into. And at the same time, the overcoat one grows into becomes inadequate and is grown out of at some point. The feeling Gogol has that there is no perfect name reflects the artificiality of the myth of the perfect signifier; there cannot be a perfect name, one that would suit a person to perfection, precisely because an identity changes and the name does not. Ironically, by the time Gogol has changed his name to Nikhil he does not feel like Nikhil for he has spent all his life as Gogol; in other words he has grown into his pet name Gogol. Besides, the fact that Nikhil is the Indian translation 
of the Russian name Nikolai, underlines the hyphenated quality of Gogol's personality as well as its capacity to take root in diferent cultures. Indeed, the personal history of the protagonist, from the origin of his name Gogol - his father was reading an English translation of Gogol's The Overcoat - to the moment he changes his names to Nikhil, is marked by a dynamics of translation in the etymological sense of the term (in Latin traducere means "to carry across"). It is also worth noting that Gogol prefers the first name Nikolai, in its Indianized version Nikhil, to Gogol, a family name turned into a first name by his father. This fluidity in the passage from first to second name denotes a capacity to negotiate the pressures of social coding induced by naming and turn the "violence inherent in the act of naming" into an expression of translated identity which sharply contrasts with a conception of identity as fixed and stable.

Another aspect of naming that the novel evidences is the social significance of the name, which not only defines one in relation to kin and delineates the line between home and the outside, but also binds the individual to the larger home of the nation, and as such is instrumental in positioning him/her within the larger lineage of the national community.

An interesting passage which eloquently expresses the way Gogol positions himself in the larger home of the American nation is the scene where he is taken on a fieldtrip to a cemetery by his school teacher and asked to look for his name on gravestones. At the end of the session, whose aim is to allow the children to realize that they are not unique and that their first names link them to a community of people who do not simply share the same language or the same name, Gogol comes to the conclusion that, unlike his peers who have all found people who had the same name as them, he is the only person called Gogol Ganguli, which generates a feeling of being out of place. At the same time, Gogol develops an unexpected kinship with people with atypical names and realises that he is not the odd one out and that there are many people with names that he has never heard before.

During the fieldtrip, Gogol is asked to copy the names written on the gravestones by laying a piece of paper over the writing and rubbing his crayon horizontally so as to duplicate the writing which is rendered "in the negative" by the concave letters.

The children begin to scamper between rows of the dead, over leathery leaves, looking for their own names, a handful triumphant when they are able to claim a grave they are related to. [...] Gogol is old enough to know that there is no Ganguli here. [...] Suddenly the crayon meets with slight resistance, and letters, one after another, emerge magically on the page: Abijah Craven, 1701-45. [...] Gogol goes from grave to grave with paper and crayon in hand, bringing to life one name after another. PEREGRINE WOTTON, D. 1699. EZEKIEL AND URIAH LOCKWOOD, BROTHERS R.I.P. (69-70)

The technique is in itself interesting for it works according to the principle of the trace, and as such can be compared with the aesthetics of the void discussed by Abraham and Torok in relation to the motif of the ghost. Abraham and Torok analyse the figure of the ghost as an embodiment of trauma and of the void left in people after the disappearance of someone dear. If we take this analogy a step further we realize that metaphorically, the ghosts that have crept into the house of the Gangulis are not Indian but are the names of these men and women who have fascinated Gogol and whom he has decided to take home and give shelter to in his bedroom, much to his mother's disapproval. 
For reasons he cannot explain or necessarily understand, these ancient Puritan spirits, these very first immigrants to America, these bearers of unthinkable, obsolete names, have spoken to him, so much so that in spite of his mother's disgust he refuses to throw the rubbings away. He rolls them up, takes them upstairs, and puts them in his room, behind his chest of drawers, where he knows his mother will never bother to look, and where they will remain, ignored but protected, gathering dust for years to come. (71)

Interestingly, the names that have attracted Gogol's attention are not foreign names; they are the names of the Pilgrim fathers, the historical core of American identity, which makes the gesture highly ambivalent, relocating the Ganguli home within the crucible of American identity while re-encoding the diasporic home. The house, which the parents had intended to be the location of their Indianness rerooted in America, is rerouted in the direction of a merging initiated by Gogol into the crucible of the American nation.

\section{The Politics of Labels and the Ethics of Labelling}

The focus on Gogol's identity crisis (and its corollary, Moushumi's yearning for France as a third space, where she can freely reinvent her identity away from the claims of both the homeland and the host country) implies somehow overstating the psychological side of the diasporic experience at the expense of other facets, such as the social or political consequences. This relatively small emphasis on the political stakes is not rare in diasporic texts and can be explained by the fact that their focus is often on characters from what Arjun Appadurai calls the "diaspora of hope," as opposed to those from the diaspora of terror who leave a country at war, or those from the diaspora of despair (6) who leave their country of origin in precarious circumstances. Gogol's father works at MIT and is a recognized academic who gets funding to do his research which places him and his family in an enviable position, as opposed to the protagonists of other recent novels such as Biju in Kiran Desai’s The Inheritance of Loss or Arjun in Hari Kunzru's novel Transmission, works which engage with more political issues and follow the trajectory of less successful migrants. ${ }^{4}$

Yet the social and political implications of labelling are touched upon in the episode narrating Gogol's attendance at a conference where he listens to a panel of academics discussing the situation of what they refer to as ABCDs, a term which is mocked by Gogol.

One day he attends a panel discussion about Indian novels written in English. [...] Gogol is bored by the panelists, who keep referring to something called "marginality," as if it were some sort of medical condition. [...] "Teleologically speaking, ABCDs are unable to answer the question "Where are you from?" the sociologist on the panel declares. Gogol has never heard the term ABCD. He eventually gathers that it stands for "Americanborn confused deshi." In other words, him. He learns that the C could also stand for "conflicted." He knows that deshi, a generic word for "countryman," means "Indian," knows that his parents and all their friends refer to India simply as desh. But Gogol never thinks of India as desh. He thinks of it as Americans do, as India. (118)

4. The newly formed interest in homecoming narratives in recent years, and the fact that these novels have somehow taken the place of narratives of the "impossible return," testifies to an emerging interest in the consequences of migration and the ethical implications of immigration in the context of the diaspora of hope. In novels like Admiring Silence by Abdulrazak Gurnah, the protagonist's return to his home is not only the consequence of a failure to succeed in the "promised land" but also the natural outcome of the protagonist's ethical questionings. 
If the emphasis of the extract is on the way labels, in this case the skilfully crafted $\mathrm{ABCD}$, are limitative, inadequate, and potentially constricting, Gogol's reaction is genuinely healthy in the sense that he not only rejects the label $A B C D$, on account of the fact that it fails to account for the complexity of his own situation, he also rejects the focus and perspective which the label triggers. Indeed, the confused deshis are discussed as if they had some medical condition, when in actual fact, the issue at stake is their lack of social validation and their positioning on the social map of the American melting pot, not to mention on the social scale of success.

The difference between self-labelling (in the sense of finding a label one is happy with) and labelling, is that labels are used by others at the expense of the people the labels refer to, and using a label to refer to one's own situation implies that one has the discursive and cognitive means to articulate a discourse on one's marginality, as well as a critical understanding of one's position in society, as Gautam Maukani humorously puts it in his novel Londonstani:

People're always trying to stick a label on our scene. That's the problem with having a fucking scene. First we was rudeboys, then we be Indian niggas, then rajamuffins, then raggastanis, Britasians, fucking Indobrits. [...] I swear I've watched as much MTV Base an Juggy D videos as they have, but still I can't attain the right level of rudeboy authenticity. If I could, I wouldn't be using poncy words like attain an authenticity, I'd be saying I couldn't keep it real or someshit. (5)

This leads me to formulate the following hypothesis: not only is there some violence in the act of labelling, but to paraphrase Derrida in De la grammatologie, this violence is epistemic as well as performative, in the sense that it turns otherness into a pathology, which is identified and which can be cured, and this medicalization of otherness is not without consequences, in the sense that it can be used as a counter-subversive force. I propose to argue this point in relation to Guillaume Le Blanc's theory of social invisibility.

In his book L'Invisibilité sociale, Le Blanc stresses the ethical dilemma produced by acknowledging the existence of precarious lives rather than turning a blind eye to them. Indeed, whilst failing to acknowledge the presence of marginalized people dooms them to a lifetime of social invisibility and justifies the absence of response to their case, acknowledging their existence as a marginalized category that needs help is equally problematic in ethical terms, for it condemns them to the long-term category of second-class citizens who need to be cared for as sick bodies rather than as citizens. To return to the novel, resorting to labels such as ABCDs has a similar effect on the people they refer to. Rather than showcase their singularity, they brand them as dysfunctionally different from the majoritarian community.

\section{Labels and the Larger Politics of Nation Building}

On a more general level, the time span of the novel, as well as the fact that the narrative embraces two generations of Indians - first and second generation migrants - in the second half of the twentieth century, positions the text at the end of a long line of redefinitions of the contours of American citizenship in the modern period. At the present time, it has become clear that national identity is linked to ethnicity, but that labels such as "white" and "black" have shifted polarities and have been conveniently redefined to accommodate certain political agendas. In the last two decades, studies of whiteness and the instrumentalization of race have shed valuable light on the way race has been, 
and is still being used as a powerful weapon of social domination, and can occasionally be used to silence certain minorities and crush their political claims. In Whiteness of a Different Colour: European Immigrants and the Alchemy of Race, Matthew Frye Jacobson ${ }^{5}$ analyzes how the criteria which make people eligible to become American citizens have changed over the years, from the Naturalization Act of 1790, which stipulated that only white men could become American citizens, onwards. The definition of eligibility then changed in the period running from 1840 to 1924, when quotas were based on the number of nationals of a given country according to the 1890 census. In 1910 individuals who were non-white or less white suffered severe discrimination, whereas the Bhagat Singh Thind v. US case (1923) overturned a previous ruling denying citizenship to a Japanese, non-Caucasian person. More recently, the crisis of the "melting pot" turned "salad bowl" had been analyzed in terms of the conspicuousness of some groups as opposed to others in the context of a gradual absorption of the less conspicuous ones into the vortex of the nation. Novelist Philip Roth in particular, has expressed the contextual change in the following terms, referring to his own experience as a Jewish American child growing up in Newark after the war:

When the cream of Miami is the Cuban bourgeoisie, and the best students at MIT are Chinese, and not a candidate can stand before a democratic presidential convention without flashing his racial or ethnic credentials - when everybody sticks out and doesn't seem to mind, perhaps Jews are less likely to worry too much about their sticking out; less likely in fact to stick out. (Roth in Milbauer and Watson 4)

Minorities have not only been gradually absorbed, to the extent that some of them have become less conspicuous, they have also served to revive and strengthen some of the core values of American identity; the taste for entrepreneurship of the Asian community has often been celebrated as part of the "model minority discourse" for example. ${ }^{6}$

In order to reposition the novel in the wider context of race relations in the United States, it is worth pointing out that it taps into an imaginary of ethnic unease and charts the complicated journeys of two second-generation migrants - Gogol and Moushumi - in search of their identity, whilst shunning the more complicated issues linked to identity politics and the integration of minorities. These issues are left outside the picture and symbolically relegated to a peripheral position, as when the Gangulis discover that their mail box - a strong symbolic link between inside and outside - has been graffitied

5. For further discussion of "whiteness," as well as colour and American citizenship, see David Roediger, Coloured White:Transcending the Racial Past and The Wage of Whiteness: Race and the Making of the American Working Class.

6. In his book Imagining the Nation, Asian American Literature and Cultural Consent, David Leiwei Li analyzes the dynamics of the social mobility of the minorities in America in the second half of the twentieth century, and in particular that of the changing status of Asians. Starting with an analysis of changes in their legal status - from marginalized migrants denied citizenship to the status of Asian Americans, mainly after the Bhagad Sing Thind v. US decision - Leiwei $\mathrm{Li}$ analyses how the Asians have often been praised on account of their ability to integrate successfully, but also rather conveniently used to re-assert and revive the values of the American dream and play one minority against another. Leiwei $\mathrm{Li}$ stresses the fact that they were used as a political tool in order to showcase the values of the American Way of Life they had supposedly embraced. Far from being flattering towards the Asians, the model minority discourse contributed to essentializing them. On closer analysis, and this has been stressed by Li, what was really at stake was an underlying agenda which aimed at justifying the disengagement of the federal government in its support of minorities. The example of the Asians being put on a pedestal was an implicit way of suggesting that other minority groups could, and should learn to fend for themselves, as the Asians had done. Leiwei Li substantiates his point by analyzing the subtext of a speech made by Ronald Reagan in 1983 in which he said that Asians helped preserve "the bedrock values of America," "the sacred worth of human life, religious faith, community spirit, fiscal responsibility, cooperation and love": "At a time when it is proposed that hundreds of billions be sent to uplift Negroes and other minorities, the nation's 300,000 Chinese-Americans are moving ahead on their own - with no help from anyone else.” (Reagan in Li 9) 
and bears the word "Gang" instead of Ganguli. The shortening of the name "Ganguli" to Gang is, at the same time, a symbolic mutilation of the name and a violent rewriting of the success story of the Gangulis, and in particular Ashoke's scientific achievements, into a collective definition suggesting a loss of individuality and the fantasized status of immigrants as disrupting the social order. This sense of the collective is conveyed through the depiction of an imaginary "mob."

Moreover, the emphasis that the novel places on successful immigrants renders the trajectory of the less successful migrants less visible, and leaves their economic difficulties unspoken. By celebrating the success of the model migrants, and foregrounding their psychological in-betweenness as the main challenge in life, Jhumpa Lahiri writes out, as it were, the "unmelted" components of the melting pot.

\section{Conclusion}

In this article I have tried to shift focus away from the psychological emphasis often placed on questions of mis-naming and mis-labelling in order to reveal other aspects of the question explored by Lahiri. Reclaiming the lost voices, a gesture similar to Gogol's attempt to bear witness to the forgotten existence of the first immigrants, has become a vital gesture in diasporic studies, in the sense that the politics of the text is often buried in its nooks and crannies. As the successful trajectories of migrants from the diaspora of hope have often become the focus of diasporic novels, the less glorious path of other types of migrants, in particular exiles or asylum seekers, has become less visible. Few novels depict the sorry plight of asylum seekers and even fewer novels portray in any detail the squalid dwellings they inhabit, or the traces that malnutrition and poor living conditions have left on their bodies. Yet these issues are far more important than the psychological unrest of characters who, like Gogol, try to come to terms with their identity. Hence my attempt in this article to focus on the "negative" of the text in the photographic sense of the term, so as to reposition the perceptual lens in order to illuminate more than Gogol, Moushoumi and Ashima alone. This meant taking the tip given by Gogol's teacher during the trip to the cemetery at face value and focusing not on what is immediately visible but on what needs to be retrieved. The analogy implies that one should not look at what is immediately given but at the form, at what emerges outside the lines, in this case the lives that gravitate towards the periphery of existing labels. The ABCDs are surrounded by a large crowd of what we could call the Existing Invisible Deshis (EIDs), a population that the novel, in passing, invites us to take a look at.

Françoise KRÁL

University of Caen Basse-Normandie 


\section{Works Cited}

Aвraham, Nicolas, and Abraham Torok. "The Topography of Reality: Sketching a Metapsychology of Secrets." Oxford Literary Review 12.1-2 (1990): 63-8.

Appadurai, Arjun. Modernity at Large: Cultural Dimensions of Globalization. Minneapolis: U of Minnesota P, 1996.

Balibar, Etienne, and Immanuel Wallerstein. Race, Nation, Class: Ambiguous Identities. London: Verso, 1988.

Bнавна, Homi K. The Location of Culture. 1994. London: Routledge, 1996.

Derrida, Jacques. De la Grammatologie. Paris: Minuit, 1967.

Desai, Kiran. The Inheritance of Loss. London: Penguin, 2006.

Fanon, Frantz. Black Skin, White Masks. London: Pluto, 1986. Trans. Charles Lam Markmann. Peau noire, masques blancs. Paris: Seuil, 1952.

Jacobson, Matthew Frye. Whiteness of a Different Colour: European Immigrants and the Alchemy of Race. Cambridge: Harvard UP, 1999.

KráL, Françoise. "Shaky Ground and New Territorialities in Brick Lane by Monica Ali and The Namesake by Jhumpa Lahiri." The Journal of Postcolonial Writing 43. 1 (2007): 65-76.

- Critical Identities in Contemporary Anglophone Diasporic Literature. Basingstoke: Palgrave Macmillan, 2009.

Kunzru, Hari. Transmission. New York: Plume, 2004.

Malkani, Gautam. Londonstani. London: Penguin, 2006.

Milbauer, Asher Z., and Donald G. Watson, eds. Reading Philip Roth. New York: St Martin's P, 1988.

LE Blanc, Guillaume. L'Invisibilité sociale. Paris: PUF, 2009.

LI, Leiwi. Imagining the Nation, Asian American Literature and Cultural Consent. Stanford: Stanford UP, 1998.

Munos, Delphine. "The Namesake by Jhumpa Lahiri: The Accident of Inheritance." Commonwealth, Essays and Studies 30. 2 (Spring 2008): 106-17.

-. After Melancholia: A Reappraisal of Second Generation Diasporic Subjectivity in the Work of Jhumpa Labiri. Amsterdam: Rodopi, 2013.

RILEY, Denise. "Am I that Name?” Language, Discourse, Society. Basingstoke: Palgrave Macmillan, 1988.

-. The Words of Selves: Identification, Solidarity, Irony. Stanford: Stanford UP, 2002.

Roediger, David. The Wage of Whiteness: Race and the Making of the American Working Class. New York: Verso, 1991.

- Coloured White: Transcending the Racial Past. Berkeley: U of California P, 2002.

Sartre, Jean-Paul. Existentialism and Humanism. London: Eyre Methuen, 1973. Trans. Philip Mairet. L'Existentialisme est un humanisme. Paris: Nagel, 1946. 